\title{
Employers' strategies for workers' motivation in selected fast food companies in Port Harcourt, Nigeria
}

\author{
B. I. Isife* and C. O. Albert \\ Department of Agricultural and Applied Economics/Extension, Rivers State University of Science and Technology, \\ Port Harcourt, Nigeria. \\ Accepted 18 July, 2012
}

\begin{abstract}
The study examined employers' strategies for workers' motivation in selected fast food companies in Port Harcourt. Specifically, the study identified the motivational techniques adopted by the fast food companies, examined the workers' perception on the motivational techniques used and ascertained the extent to which the motivational techniques enhance workers' performance. A sample of three fast food companies was chosen. They included Mr. Biggs, Tantalizers and Best-Bite. In each of these companies, opinions of one hundred workers were sought giving a total of $\mathbf{3 0 0}$ respondents. Data percentages, means scores, regression analysis and analysis of variance. The results were collected by the use of structured questionnaires, and the data were analysed using established prompt payment of salary $(85.3 \%)$, job rotation/ shift duty (95\%), good working environment (95\%), gift and material benefit outside regular salary (95\%) as the most effective motivational techniques used. These factors agreed with the perception of the workers on the motivational tools that enhance workers' performance. The result reveals also that a unit increase in motivational tools increases workers' performance showing positive relationship. There was significant difference in the motivational techniques used by the three fast food companies at $P<0.05$. The study recommended, among others, that in addition to prompt payment of salary, the salary of the workers should be increased to motivate and enhance workers' performance considering the economic melt-down that have affected the prices of goods and services globally.
\end{abstract}

Key words: Employers' strategies, workers' motivation, food companies.

\section{INTRODUCTION}

Pecuniary rewards play a tremendous part in the satisfaction of employee's need, act as a status symbol, and a source of recognition and esteem to the individual (Fillipo, 1980). The individual performance of an employee in an organization plays a very vital role in helping the organization to achieve its aim which is profit maximization. According to Stoner (1986), individual abilities and the individual's understanding of what behaviour is, is necessary in order to achieve high performance. Thus, the overall organizational performance depends on the individual performance of organization's employees. This has led organizations to continually look for avenues to increase workers' inputs subordinates by

\footnotetext{
${ }^{*}$ Corresponding author. E-mail: benisife@yahoo.com.
}

through the motivation of their workers or employees. Hence, managers or organizations motivate their doing those things which the subordinates hope will satisfy their innate drive and induce them to act in a desired manner. This brings to fore, the role of motivational tools in employees' performance.

Anything that impels, propels or energizes an individual to behave in a particular way is motivation. Jones (1995) stated that motivation has to do with how behaviour gets started, energized, sustained, directed, stopped and what kind of subjective reaction is present in the organization while all these are going on. This was buttressed by Kalagbor (2000), who saw motivation as anything that impels, energizes, causes and sustains employee behaviour towards effective and efficient performance of his/her job. Workers' low productivity has persistently remained a striking problem in organizations in most 
Table 1. Motivational Techniques used by Mr. Biggs, Tantalizers and BestBite

\begin{tabular}{|c|c|c|c|c|c|c|c|}
\hline \multirow{2}{*}{ Techniques } & \multicolumn{2}{|c|}{ Mr. Biggs } & \multicolumn{2}{|c|}{ Tantalizers } & \multicolumn{2}{|c|}{ Best Bite } & \multirow{2}{*}{$\begin{array}{l}\text { Total No. of } \\
\text { responses }\end{array}$} \\
\hline & Snr & Jnr & Snr & Jnr & Snr & Jnr & \\
\hline Prompt payment of salaries & $50(100)$ & $42(4)$ & $50(100)$ & $33(66)$ & $50(100)$ & $31(62)$ & 85.3 \\
\hline Adequate salary level & $10(20)$ & $5(10)$ & $11(22)$ & $6(12)$ & $12(24)$ & $9(18)$ & 17.6 \\
\hline Respect for both senior and junior staff & $5(10)$ & $8(16)$ & $6(12)$ & $10(20)$ & $8(16)$ & $11(22)$ & 16.0 \\
\hline Promotion for high level & $10(20)$ & $5(10)$ & $15(30)$ & $10(20)$ & $11(22)$ & $10(20)$ & 20.3 \\
\hline Good supervision & $11(82)$ & $40(80)$ & $46(92)$ & $40(80)$ & $50(100)$ & $40(80)$ & 85.6 \\
\hline Challenging worker due to work enlargement & $40(80)$ & $11(22)$ & $40(80)$ & $45(90)$ & $40(80)$ & $48(96)$ & 84.3 \\
\hline Provision of job security & $10(20)$ & $20(40)$ & $10(20)$ & $9(18)$ & $10(20)$ & $13(26)$ & 31.0 \\
\hline Good working relationship among managers, supervisors and workers & $29(58)$ & $45(90)$ & $36(72)$ & $20(40)$ & $25(50)$ & $18(36)$ & 49.3 \\
\hline Good working environment & $50(100)$ & $45(90)$ & $50(100)$ & $45(90)$ & $50(100)$ & $45(90)$ & 95.0 \\
\hline Good corporate rules and regulations & $40(80)$ & $45(90)$ & $46(92)$ & $48(96)$ & $42(84)$ & $46(92)$ & 89.0 \\
\hline Recognized remarkable achievements & $10(20)$ & $11(22)$ & $10(20)$ & $9(18)$ & $10(20)$ & $13(26)$ & 21.0 \\
\hline Independent decision making & $5(10)$ & $1(2)$ & $6(12)$ & $4(98)$ & $8(16)$ & $5(10)$ & 9.6 \\
\hline Provision of transport facilities allowance & $34(68)$ & $20(40)$ & $38(76)$ & $20(40)$ & $40(80)$ & $21(42)$ & 57.6 \\
\hline Job rotation/shift duty & $50(100)$ & $45(90)$ & $50(100)$ & $45(90)$ & $50(100)$ & $45(90)$ & 95.0 \\
\hline Provision of housing/housing allowance & $40(80)$ & $22(44)$ & $45(90)$ & $16(32)$ & $46(92)$ & $45(90)$ & 71.3 \\
\hline Gift and material benefit outside regular salary & $50(100)$ & $45(90)$ & $50(100)$ & $45(90)$ & $50(100)$ & $45(90)$ & 95.0 \\
\hline Praises given to workers regularly & $20(40)$ & $11(22)$ & $19(38)$ & $10(20)$ & $21(42)$ & $20(40)$ & 33.6 \\
\hline
\end{tabular}

Snr, senior;Jnr, junior staff; * Figures in parentheses are in percentage.

developing economies especially in Nigeria (Uche, 1982). When a worker feels dissatisfied and unhappy about the motivational techniques cum rewards system adopted by the organization, such a worker's level of performance and efforts tend to drop.

The workers are bound to be careless about the organization's success (Amugo, 2008). That is why the workers in the developing economies like Nigeria are on the average, often seen or accused of a carefree attitude to work, inefficiency, unproductive and lack of sense of duty (Uche, 1982; Amugo, 2008). All these non-challant acts are detrimental to corporate existence of business organizations, and therefore, need urgent solution.
It is on this premise that the study on employers' strategies for workers' motivation in selected fast food companies in Port Harcourt was designed. The study, therefore sought to answer the following questions. How do the workers perceive the motivational tools used by these food companies? Are they appropriate? And if appropriate, to what extent do the motivational techniques motivate the employees?

\section{Hypothesis}

$\mathrm{H}_{0}$ : There is no significant difference in the motivational techniques of Mr. Biggs, Tantalizers and Best-Bite.

\section{RESEARCH METHODOLOGY}

The study was carried out in Port Harcourt, the capital of Rivers State. Rivers State is one of the states that made up the Niger Delta region in the South- South geographical zone of Nigeria. It is responsible for over $45 \%$ of crude oil produced on-shore in the country and almost $100 \%$ of the gas currently being exported to several countries of the world in liquefied form. It is one of the fastest growing metropolitan cities in the country. There are ten (10) fast food companies in Port Harcourt metropolis, three fast food companies namely: Mr. Biggs, Tantalizers and Best Bite were purposively selected because of their staff strength. A minimum of thirty staff strength was considered. Fifty junior staff and fifty senior staff were selected from each company for the survey-giving a total of 100 respondents from each fast food company. A total of 300 respondents formed the sample size. Data collected were analysed using percentage, regression coefficient and mean 
Table 2. Workers' view of motivational techniques that can enhance performance.

\begin{tabular}{lcccc}
\hline Techniques & Mr. Biggs & Tantalizers & Best Bite & $\bar{X}$ of means \\
\hline Prompt payment of salaries & 4.15 & 4.15 & 4.15 & 4.15 \\
Adequate salary level & 1.30 & 2.10 & 1.20 & 1.16 \\
Respect for both senior and junior staff & 1.20 & 1.30 & 1.20 & 1.23 \\
Promotion for high level & 1.20 & 1.15 & 1.30 & 1.21 \\
Praises given to works regularly & 2.10 & 2.10 & 2.50 & 2.23 \\
Good supervision & 3.20 & 3.30 & 3.10 & 3.20 \\
Challenging worker due to work enlargement & 1.20 & 1.15 & 1.20 & 1.16 \\
Provision of job security & 1.20 & 1.15 & 1.10 & 1.15 \\
Good working relationship among managers, supervisors and workers & 3.00 & 3.15 & 3.10 & 3.08 \\
Good working environment & 4.00 & 4.00 & 4.00 & 4.00 \\
Good corporate rules and regulations & 2.10 & 2.20 & 2.10 & 2.13 \\
Recognized remarkable achievements & 1.51 & 1.10 & 1.30 & 1.23 \\
Independent decision making & 1.10 & 1.15 & 1.20 & 1.15 \\
Provision of transport facilities /allowance & 2.20 & 2.30 & 2.20 & 2.23 \\
Job rotation/shift duty & 3.15 & 3.10 & 3.30 & 3.18 \\
Provision of housing/ housing allowance & 1.10 & 1.20 & 31.50 & 1.26 \\
Gift and material benefit outside regular salary & 3.73 & 3.75 & 3.75 & 3.75 \\
\hline
\end{tabular}

Mean cut-off $=2.50 ; \geq 2.50$ is effective, $<2.50$ not effective.

scores. The analysis of variance (ANOVA) was used to test stated hypothesis.

\section{RESULTS AND DISCUSSION}

Table 1 shows the motivational techniques adopted by the three fast food companies studied. The result reveals that prompt payment of salaries (85.3\%), good work environment $(5 \%)$, gift and material benefit outside regular salary $(5 \%)$, job rotation/shift duty $(95 \%)$, good corporate rules and regulations (89\%) and challenging worker due to work enlargement $(84.6 \%)$ were the major motivational techniques used. The result confirms Herzberg (1959), cited in Johnnie (2002) that recognition, challenging work, job security, advancement and growth are the only motivation factors that can actually motivate an employee. But in the area of job security, which was $31 \%$, the establishments were lacking.

Table 2 established the perception of workers' on motivational techniques that can enhance performance using a meant cut-off point of 2.50 . The result reveals that prompt payment of salaries (4.15), good supervision (3.20), good working environment (4.00), good working relationship among managers, supervisors and workers (3.08), job rotation/shift duty (3.18) and gift and material benefit outside regular salary (3.75) were the motivational tools that enhance job performance in the establishments. Kootz and Weihrich (1993) argued that motivation is the most appealing, stimulating and rewarding mechanism that can motivate the Nigerian/African worker.

Table 3 shows that the constant (a)is 82.300 . This is the level of workers' performance without motivation. The regression coefficient is 1.278 . It is positively significant implying a positive relationship with workers' performance, that is, increase in motivation will increase workers' performance in absolute terms. A unit increase in motivation will increase workers' performance by 1.278 and a $100 \%$ increase in motivation will increase workers' performance by $127.8 \%$. Gujarah (2006), Jones and George (2003) conclude that as people join organizations to meet their needs, so also do organizations employ people to achieve their goals, and that while trying to achieve their targets and goals, organizations use institutionalized mechanisms such as structures, procedures, systems and rules that often run contrary to human needs and expectations.

From Table 4 , the result shows that $\mathrm{f}$-cal $=2.238$ was less than $f-t a b=3.23$. Therefore, the null hypothesis was accepted, showing that there was no significant difference in the motivational techniques used by the three organizations studied at $\mathrm{P}<0.05$.

\section{CONCLUSION AND RECOMMENDATIONS}

The three organizations studied adopted motivational strategies to enhance workers' performance. The regression result showed a positive relationship between the two variables (motivational techniques and workers' performance). This established that there was not just a significant relationship but a significant positive relationship between workers' performance and the motivational strategies of the firms. Out of the seventeen identified 
Table 3. Summary of regression coefficient showing the relationship between motivational tools and workers' performance.

\begin{tabular}{lcccccc}
\hline Variable & $\begin{array}{c}\text { Regression } \\
\text { coefficient }\end{array}$ & $\begin{array}{c}\text { t- } \\
\text { values }\end{array}$ & t-tab $\frac{\alpha}{2} \mathbf{2 9 9}$ & $\begin{array}{c}\mathbf{f}- \\
\text { values }\end{array}$ & $\begin{array}{c}\text { f-tab 0.05; } \\
\mathbf{1 . 2 9 9}\end{array}$ & $\mathbf{R}^{\mathbf{2}}$ \\
\hline Constant & 82.300 & 66.671 & 1.960 & 4.412 & 3.84 & 0.501 \\
motivation & 1.278 & 12.100 & & & & \\
\hline
\end{tabular}

$W p=82.300+1.278 \mathrm{mot}+\mathrm{e}(66.671)(12.100) ; \mathrm{t}$-value are in brackets.

Table 4. ANOVA result showing the difference in motivational techniques of Mr. Biggs, Tantalizers and Best-Bite.

\begin{tabular}{lccccc}
\hline Source of variation & Sum of square & df & Mean squares & f-cal & f-tab \\
\hline Due to regression & 50444.314 & 16 & 3152.77 & & $0.05,2,32$ \\
Between items & 124.353 & 2 & 62.175 & 2.236 & 3.23 \\
Due to residual & 888.980 & 32 & 27.786 & & \\
Total & 559951.647 & 50 & 1117.153 & & \\
\hline
\end{tabular}

motivational techniques outlined in the questionnaire, nine were rightly perceived by the employees. The others, though present in the organizations, their levels were poor to have induced workers' performance.

In view of the emerging facts, the following recommendations are advanced. In addition to prompt payment of salary, the salary of workers should be increased for higher workers' performance in the establishments. Secondly, the issue of job security and cordial relationship among management, supervisors and other workers should be seriously encouraged. This is because an employee who does not have faith in job could easily be won over by a company with job security. Finally, employees should be part of decision making since these decisions directly affect them.

\section{REFERENCES}

Amugo NM (2008). Employers' strategies for workers' motivation: A survey of selected fast food companies in Port Harcourt. M.Sc project report, Department of Agricultural Economics and Extension, University of Science and Technology, Port Harcourt pp.1-66.
Fillipo EB (1980). Personal Management. New York, McGraw-Hill Book Company p.7.

Gujarah DN (2006). Basic economics. $4^{\text {th }}$ edition. New York. Tata McGraw Hill pp.23-34.

Herzberg F, Mausner B, Snyderman BB (1959). The motivation to work. New. York: Wiley.

Johnnie PB (2002). Organizations behaviour and Organization Theory (A Theoretical and Philosophical Perspective). Lagos, University of Lagos Press pp.65-93.

Jones GR (ed) (1995). Nebraska symposium of Motivation. University of Nebraska Press p.6.

Jones GR, George JM (2003). Contemporary Management Third edition. New York, McGraw-Hill p.126.

Kalagbor SB (2000). An Introduction to Contemporary Political Science and public Administration. Port Harcourt, Belak Services pp.222-223.

Kootz H, Weihrich H (1993). Management: A Global Perspective (Tenth Edition). McGraw Hill International p.365.

Stoner JAF (1986). Management. (Third edition). New Jersey, Prentice Hall p.579.

Uche C (1982). The Nigeria Attitude to Work: A Theoretical Examination. Seminar Presentation at the National Conference on Human Resources Management in Nigeria. University of Nigeria, Enugu Campus 10:45. 